\title{
SAMUEL, MICHAEL AND HYLEEN MARIAYE, EDS. 2016. CONTINUITY, COMPLEXITY, AND CHANGE: TEACHER EDUCATION IN MAURITIUS. ILLINOIS: COMMON GROUND PUBLISHING.
}

\author{
Reviewed by Jennifer Feldman \\ Stellenbosch University \\ Email: jennf2103@gmail.com
}

This book, situated in teacher education at higher institutions within the contextual landscape of Mauritius as a small island developing state, provides insight into the challenges and lived experiences of the individuals and their collaborating partners spanning a forty year period. Edited by Michael Samuel (University of KwaZuluNatal, South Africa) and Hyleen Mariaye (Mauritius Institute of Education, Mauritius), this book includes personal narratives as well as a critical analysis of the on-going development of teacher education and practice in the broader field of comparative and international education. The biographical narrative data was collected from participants across three generations from the Mauritius Institute of Education (MIE) and collated and analysed by the project research team. Despite the chapters being authored by different individual team members or groups of individuals, the final script produced is described as a collaborative effort by those involved in the research process.

The book consists of nine chapters which are divided into four sections. The first section sets out the research project on which this book is based within the landscape of teacher education in Mauritius. Chapter 1 provides a contextual overview of the evolving educational landscape during the post-independence era in Mauritius. This includes a

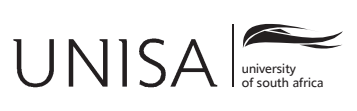

Education as Change

Volume 20 | Number 3 | 2016 | pp. 243-246

www.educationaschange.co.za
DOI: http://dx.doi.org/10.17159/1947-9417/2016/1536 Print ISSN 1682-3206 | Online 1947-9417

(C) 2016 The Author 
discussion on the historical, economic, social, cultural and political development of Mauritius's education system and the current challenges it faces. The chapter includes a brief overview of the Mauritius Institute of Education (MIE) and sets the stage for the forthcoming narratives.

Chapter 2 describes the background to this specific research project and discusses the rationale for the methodological processes involved in using narrative inquiry as a way of documenting the historiography of an institution. This chapter describes the manner in which the data was produced and analysed. As the research is documented as a form of personal narrative by the researchers involved in the project, this chapter offers an honest critique and reflexive account of the ethical challenges and dilemmas involved as an 'insider researcher' (as a staff member) of an institution. The chapter includes a discussion on the way in which the researcher MIE staffmembers adopted both a reflective and reflexive stance during the process in order to ensure that the research accurately presented the overall culture, context and texture to build a narrative framework that documented the history of MIE as an institution within the overall historical context of the country. This chapter includes a discussion on the broader discourse of SIDS and higher institutions of teacher education, and draws on international research agendas to understand how higher education in small state contexts is able to respond to global forces. Before moving on to the second section of the book, this section describes how the data was analysed and how the three themes which are discussed in the next section emerged, namely the pioneers, the managers and the foot soldiers.

The second section of this book chronicles the unfolding history of MIE via the personal narratives of three generations of MIE professionals. These narratives provide an in-depth insider view into the educational issues of teacher education and the national agenda of education which has spanned the four decades of this academic community. Chapter 3, termed 'The Pioneers', discusses the establishment of MIE and the role that it played as an educational institution within a particular socio-economic and political climate. Chapter 4 describes the role that the institution's managers played at MIE during a period of institutional reconstruction and expansion. These narratives are situated between the MIE founding academics and the staff who were tasked with developing and growing the institution within a particular historical period. Chapter 5 presents the narratives of new teacher educators - 'The Foot Soldiers' - and the role they played in developing the institution between the years of 2005 to 2011. This discussion describes the challenges of new teacher educators as they transition from being school teachers to becoming teacher educators. What this section highlights, through the narratives of the MIE teacher educators, is how structures within higher institutions are able to mediate the professional learning of novice teacher educators.

The third section of the book draws on the emerging themes from the narratives presented in the previous three chapters. Chapter 6 focuses on the individual and organisational levels involved in the process of becoming a professional teacher educator at MIE and problematises the identity shift that teachers make as they move 
from being a teacher in a school context to becoming a teacher educator at a higher institution. Drawing on the narratives in the preceding chapters, the analytical focus in this section considers the personal, institutional and contextual resources that teacher educators mobilise in their efforts to develop agency within their new teacher educator roles. The discussion in this chapter foregrounds the notion of what it means to shift from a teacher identity to that of a scholarly identity within a higher institution.

Chapter 7 includes three sections which develop the analysis of teacher educator identities at the organisational level and discuss the power structures within the institutional field and across macro-level contexts. In the first section, key issues of productivity, quality and diversity within the current trend of privatisation and public sector retrenchment are challenged in relation to the future direction of public higher education within the context of Mauritius as a SIDS. This section focuses on how MIE, as a public sector institution, is responding to the influences from the private productorientated discourses. It considers how practices that have now come to dominate the higher institution field impact on an institution such as MIE, which, situated in a small island country, was previously sheltered from these considerations. The discussion centres around how financial aspects of public institutions need to become entrepreneurial in order to respond to the influences that the competitive market of private institutions is forcing on public institutions. A second focus of this section is on how higher institutions can respond to the changing field of teacher education if "teacher education is to breed the new intellectual teacher, one who thrives in communities of inquiry' (Mariaye 2016, 128). This challenge, which is argued as requiring significant additional resources of time and manpower, is considered at a time when governments are retracting their funding and allowing the private sector to provide the funding for higher institutions.

Section two analyses how an institution such as MIE is able to gain legitimacy as it negotiates the relationship between state, industry and higher education and considers what alternative institutional structures and practices MIE can develop. Section three uses the personal and professional narratives presented in chapters 3, 4 and 5 to develop what is described as a 'typology of entrepreneurs' who are able to challenge the prevalent institutional narratives and higher institutional power structures to consider innovative and strategic approaches that will better meet the needs of public higher institutions in smaller countries. Finding ways in which higher education institutions can gain legitimacy within the current professional, political and social contexts, this section suggests that there are three different categories of entrepreneurs highlighted by the biographies of the participants' narratives. These categories include the reformist, the mediator and the problem solver. Each of these categories offer an analysis of how the different groups of teacher educators were able to respond to the challenges of the changing practices and structures within the context of MIE as a higher educational institution in a small island state. This section goes on to include a consideration of the nature of the major shifts in curriculum reform within the schooling sector and 
how these impact on the organisational choices and the teacher educators at MIE. It considers how individuals are able to exert 'entrepreneurial agency' in order to shift and change their teaching to respond to the new requirements.

The last section of the book responds to the focus of the book as captured in the title 'Continuity, complexity, and change' examining the intersection between the impact of the forces from the personal, institutional and national level on higher educational institutions in SIDS. Here the discussion centres on the process by which SIDS higher educational institutions are able to negotiate the tensions, challenges and changes in institutional policy, theory and research. Included in this section is a summative response written by the editors of the book that foregrounds the issues and potential responses to complex and multiple forces impacting on teacher education within small island contexts. Presented in three broad themes this section includes a discussion on the nature of the partnerships that were forged, enabling an institution such as MIE to navigate the fields of education, politics, economics, sociology and public administrative terrain in order to provide sustainable higher education within the broader spectrum of higher education.

The final chapter in the book offers a reflexive engagement with the key learning points emanating from the research project. This chapter includes a discussion on the future of teacher education in Mauritius and highlights issues in lessons of policy, practice and research from the analysis of the MIE narratives. As an example of research borrowing, this chapter debates how the trajectory of change can be managed by discussing the collaborative partnership which was established between MIE and the School of Education at the University of KwaZulu-Natal. This provides an example of how SIDS researchers, in response to the challenges and possibilities discussed in the book, can activate their scholarly work by engaging in dialogues across international comparative research communities of teacher education.

In closing, this book deals with issues that move beyond those encountered within the higher institution of MIE within the context of small island states. The narrative presented offers a critical analysis of teacher education programmes at higher institutions which moves beyond the contextual situation of SIDS to provide insight into the complexity of creating and sustaining teacher education programmes within the global teacher education discourse. This book is thus relevant to those who are working in the field of teacher education situated within particular contexts, such as SIDS, as well as within the global context that considers the provision of innovative and culturally sensitive responses to contextual challenges in teacher education.

\section{REFERENCE}

Mariaye, H. 2016. Organizational development in a teacher education institute: The search for legitimacy? In Continuity, complexity, and change: Teacher education in Mauritius. Edited by M. Samuel and H. Mariaye, 125-143. Illinois: Common Ground Publishing. 